\title{
The ROLE OF THE Institute For Missiological AND ECUMENICAL RESEARCH IN THE PAST AND PRESENT
}

Author:

Attie van Niekerk ${ }^{1}$

\section{Affiliation:}

${ }^{1}$ Institute for Missional and Ecumenical Research,

University of Pretoria,

South Africa

\section{Correspondence to:}

Attie van Niekerk

e-mail:

asn@xsinet.co.za

Postal address:

PO Box 38465, Garsfontein -

Oos, Gauteng, 0060,

South Africa

\section{Keywords:}

IMER; missiological

research; ecumenical

research; University of

Pretoria; missionary calling of the church

\section{Dates:}

Received: 11 July 2008

Accepted: 20 Aug. 2008

Published: 17 Dec. 2009

How to cite this article:

Van Niekerk, A., 2009,

'The role of the Institute

for Missiological and

Ecumenical Research in the past and present', Verbum et Ecclesia 30(3), Art. \#175, 7 pages. DOI: 10.4102/ve.v30. i3.175

\section{This article is available} at:

http://www.ve.org.za
(C) 2009. The Authors. Licensee: OpenJournals Publishing. This work is licensed under the Creative Commons Attribution License.

\section{ABSTRACT}

IMER, the Institute for Missiological and Ecumenical Research, was initiated in 1979, when the 20th century missionary movement in the Dutch Reformed Church had already started to unravel. IMER's history gives us insight into these events. IMER has focused on the missionary calling of the church and on guiding the church in its broad responsibility to Southern African society. IMER conducted a comprehensive study on the unfinished task in the eighties, from which a variety of other projects followed. The understanding of the task of mission has gradually broadened to include the church's responsibility to the whole of life, with faith in Christ at the centre. However, as funding for the missionary movement diminished and the university had to cut down on expenses, funding for IMER dried up. IMER is now in the same position as mission itself, and even many congregations: it has to be innovative and find new structures and new sources of funding to respond to the challenges of a new century.

'...the Dutch Reformed Church is a mission church...with a broad social responsibility.'

(Giliomee 2004)

\section{INTRODUCTION}

IMER, the Institute for Missiological and Ecumenical Research, was initiated in $1979^{1}$. It was a difficult time for such initiatives. At that time the missionary movement of the 20th century in the Dutch Reformed Church (DRC) had already started to unravel. It was three years after the riots of 16 June 1976 in Soweto, after which the country has lived in a continual state of searching its own identity. More important, however, were the uncertainties that developed within the church itself.

IMER had to serve a dying movement. It has been suggested that IMER itself should close down. Is IMER the anachronistic remains of a previous phase or did it help to pave the way towards a new beginning - perhaps a new phase? Is there such a new phase?

The missionary movement of the 20th century in the DRC commenced when the Anglo-Boer War led to a unique awakening in the church - and her mission. According to Crafford (1982:144), many souls were led to introspection and repentance by the chastening hand of God in the commandos and in the concentration- and prisoner of war camps. This led to a spiritual awakening that was conducive to the growth of missions.

The level of missionary activity increased continuously and reached its peak in the period between 1948 and 1976. Alongside apartheid, there was an idealism to Christianise and develop the country. The missionary movement was well organised and managed by the synods. In this article the term 'mission' refers to this movement with both its more attractive and less attractive attributes.

David J. Bosch was both a product and a critic of this movement. He delivered the first IMER lecture on 16 January 1990; on 17 January 1991, in a report to the University of Pretoria (UP), he commended IMER for its work. His personal library is now at the Bosch Reading Room of the Department of Religion and Missiology and IMER, at the University of Pretoria (UP).

\section{Historical background}

In 1648 a group of Dutch seamen were stranded on the north eastern shores of Table Bay for five months. The local tribesmen cared for them and traded goods with them. The seamen left with pleasant memories. Two of them, Janssen and Proot, recommended to the East India Company that they should establish a halfway post there that would bring profit to the Company but would also bring many souls to God and to the Christian Reformed Religion. The halfway post should not only bring temporary profit to the Company but also had to honour God in leading many to salvation (Du Plessis 1911:20).

This report led to the expedition of Jan van Riebeeck - later honoured as the founder of the Afrikaner nation - who landed there on 6 April 1652 to establish the halfway station. He shared the convictions of Janssen and Proot that the Christian faith had to be brought to the local people. These convictions were clearly formulated in the prayer with which the Council meetings were usually opened. On 9 April 1652 Van Riebeeck issued a declaration in which he warned his officials of the local population's tendency to steal. The officials were, however, still held responsible for maintaining good relationships. If an official's tools were stolen, he was held responsible for the loss and the official would receive 50 whip lashes for his negligence and forfeit his wine rations for eight days. When an official hit or pushed one of the local population - with or without good reason - the official would receive 50 lashes in the

1.In Afrikaans: ISWEN, the Instituut vir Sendingwetenskaplike en Ekumeniese Navorsing, originally the Instituut vir Sendingwetenskaplike Navorsing. The 'Ekumeniese' was added in about 1990 as a result of the work of Professor Dionne Crafford and Dr Gustav Gous. 
presence of the local population so that they could see that the Company intended to maintain good relationships with them (Du Plessis 1911:22,23).

Politics was not the driving force at this stage. This would change only later. Trade was a motive; the motive to run a profitable business has recently again become more prominent in the South African culture. The motivation to bring souls to God and the Christian Reformed Religion was another motive. This motive has never disappeared. In the Uniting Reformed Church, the result of the DRC's mission work, there are about 37 formerly Black and 45 formerly Coloured congregations that were established before 1900 .

The intention to maintain good relationships has not disappeared either. For example, according to the historian Hermann Giliomee (2004:408,409), in the 1920s, none of the DRC leaders propagated that the practice of separate schools and congregations be extended into separate political institutions The most authoritative voice in missions at the time, Professor Johannes du Plessis, used every opportunity to oppose discrimination based on the idea of national identity. Du Plessis supplied the framework for the idea that the DRC was in essence a missionary church with a broad social responsibility. This was before the rise of Afrikaner nationalism that led the DRC into political byways.

In 2003 Gideon van der Watt, then mission secretary of the General Synod, explained the phases through which the DRC mission has moved in the last half of the 20th century.

\section{The growth and idealism of the fifties and sixties}

This phase was marked by self-confidence, optimism and activism. Mission was seen as part of the Afrikaner's calling in Africa. It ran parallel to the apartheid politics and separate development, although the policy was also questioned (Van der Watt 2003:214). Between 1948 and 1976 about 265 (then Black) new congregations of the DRC of Africa were established along with 121 (then Coloured) congregations of the DR Mission Church (in the nineties these two churches united to form the Uniting Reformed Church).

Opposition against the mission policy and attempts at joint mission in the seventies and eighties

In this period missionary work was impacted directly by the political resistance against apartheid and white domination. The church started to reconsider her mission policies, defended herself against criticism and made efforts to adapt. Joint missions were started with members of the Black and Coloured churches. The number of DRC mission staff decreased from 1078 in 1973 to 551 in 1977. The emphasis also shifted to overseas missions (Van der Watt 2003:222). Other structures that formed part of this movement, such as the four Stofberg schools for training Black ministers, started closing down one by one.

It was in this hectic period that IMER was established at the Faculty of Theology. Soon afterwards, the (White) final year theological students no longer needed to indicate whether they were available for 'mission' - there would soon be none of the structures of the missionary movement of the 20th century left for them to be available for.

This was a time of intense political tension in the country.

Despite the resistance to apartheid on many levels, the Afrikaner churches did not heed the warnings against white privileges and about the growing gap between white prosperity and black poverty. In 1994 the General Synod of the DRC accepted a report on race relations that, in effect, advocated a Biblical justification of apartheid.
According to the journalist Schalk Pienaar

...he despaired at the DRC that could not shake off the image of being the National Party in prayer... Like an Old Testament prophet of doom, he proclaimed his concern with the fact that the rich were becoming richer and the poor, particularly vulnerable black people, poorer: "When one sees how palaces arise alongside a multitude of shacks in this country, one wonders for how long the wrath of the Almighty God will stay out".

(Giliomee 2004:510, translation AvN)

The DRC played an important role in maintaining Afrikaner power during the seventies. However, during the eighties the Afrikaner-movement began to break up and in 1990 the Afrikaner honorably handed over the political power to the majority, helping to open the way for a new democracy in the country.

This brings us to the third phase as identified by Van der Watt:

\section{Congregations took the initiative and world missions became important during the nineties}

This phase was marked by deep feelings of uncertainty. Some DRC members emigrated overseas while others escaped into their own private worlds. The initiative for missions was taken by the congregations, away from the synods; the centre of activity moved away from trained missionaries to church members; there was a shift from the focus on Africa to a global vision, from centralised control to a diversity of approaches and from working within the structures of your own church to participating in various para-church organisations (Van der Watt 2003:224). World mission initiatives were frequently triggered by the frustration caused by the tense relations locally.

What the implication of all of this was for IMER is an interesting question. IMER's role amidst all these activities was to maintain the church's focus on her calling, which was a continuation of Du Plessis's view of the DRC being a mission church with a broad social responsibility. With this as background we will now turn to the history of IMER itself. We will end with the question whether another new phase lies ahead or not.

\section{The beginning}

During the seventies, the then Mission Commission of the General Synod (Algemene Sinodale Sendingkommissie) of the DRC identified the need for an institution to lead and coordinate research into mission. They started with a bureau run by the staff of this commission. The workload soon increased to such an extent that in 1976 Professor C.W.H. Boshoff, head of the Department of Science of Religion and Missiology at UP, suggested that an institute for mission research be established at the Faculty of Theology at UP. This proposal was approved by the General Synod in 1978. The university itself approved the establishment of the institute on 25 September 1987 (Crafford 1982:485).

The first director of IMER was Dr J.M. Cronje, who had been a missionary in Zambia and later the mission secretary for the General Synod. In a Curriculum Vitae that he wrote in 1993 he stated:

When it became known that I intended to retire at the age of 65 at the end of August 1979, I was approached by Professor C.W.H. Boshoff to join the Faculty of Theology (Sec B) at UP to establish IMER. This institution was the first of its kind in South Africa. The blessing of the Lord rested on the institute and in early 1981 I was joined by Dr J.J. Kritzinger, who became the senior research officer. My service at IMER ended during 1992.

(Cronje 1993: S785/93, p6).

IMER's prime: 1981-1995

In 1981 and 1982 IMER published two extensive overviews of the history of DRC mission, one on the work in South Africa and 
neighbouring countries and one on the work outside the country, mostly in other African countries. The first to be published, in 1981, was written by Dr Cronje and entitled Aan God die dank. Geskiedenis van die Sending van die Ned. Geref. Kerk. Deel 2: Buite die Republiek van Suid-Afrika. It was followed in 1982 by Aan God die dank. Geskiedenis van die Sending van die Ned. Geref. Kerk. Deel 1: Binne die Republiek van Suid-Afrika en enkele aangrensende buurstate, written by Professor D. Crafford.

These publications were initiated by the synodical commission before the establishment of IMER, but the completion thereof by IMER was a good start for the young institute. In his preface to Deel 2, Professor C.W.H. Boshoff, chairman of the IMER board and dean of the faculty wrote: 'With the appearance of this excellent publication IMER has proven the reason for its existence' (in: Crafford, 1981, p.1). In hindsight one can ask whether it has any meaning that IMER's first project was to publish the history of the mission movement it belonged to.

The good beginning was followed by further initiatives. Dr Johan J. (Dons) Kritzinger became a temporary, part-time researcher in 1981. His post was upgraded to temporary, full-time researcher in 1987. When he became co-professor and director of IMER in 1989, IMER seemed to be well established. Kritzinger was involved in theological training and assisted with research training at the faculty. He acted as external examiner for doctoral students at various universities.

When Cronje turned 70 in 1984, Professor Dionne Crafford, professor in Missiology at UP, became the part time director of IMER.

The realisation that the missionary movement in the DRC was losing steam led to IMER's most important project, titled The Unfinished Task in South Africa (Die Onvoltooide Sendingtaak in Suid-Afrika). This project lasted from 1985 to about 1987. It was the initiative of Rev. Eddie Bruwer who recruited Kritzinger for this task from the (Black) DRC in Africa congregation of Maandagshoek. The project published 31 reports covering the unfinished task in Bophuthatswana, Gazankulu, KaNgwane, KwaNdebele, Lebowa, Swaziland, Venda, Northern and Eastern-Transvaal countryside, Kragveld, Pretoria, the PWV area, Northern Cape, Southern and Western Transvaal countryside, etc. Unreached people groups were highlighted. Cronje (1990:19) stated that, with this report, IMER had given South Africa its 'first scientific overview of the state of religion in the country'. The reports showed that approximately $25 \%$ of the SA population were not Christians and that the black independent churches were 'growing at an amazing rate.' In the years after this Kritzinger continued to study the national trends in statistics on religion.

The project led to a Mission Congress that was held in July 1988 at UP. Kritzinger was the secretary of the committee that arranged the Congress and also the author of The Unfinished Task in South Africa which IMER published in 1988 to coincide with the Congress. The Congress did not, however, prevent the demise of the mission movement in the DRC. In 1991 IMER submitted an unpublished report to the General Synod's Commission for Mission, containing the results of a research project entitled Reasons for the low level of interest in mission in the Dutch Reformed Church (Oorsake van die lae sendingbelangstelling in die NG Kerk).

Kritzinger continued the work that was started in The Unfinished Task in South Africa. Numerous research projects followed, with the role of the church in society as a central theme. It started with The Influence of Religion on Development (Die Invloed van Religie op Ontwikkeling 1987-1990) and was followed by The Church and the (wellbeing of) the environment (Die Kerk en die (welsyn van) die Omgewing), The Church and Labour (Die Kerk en die Arbeidslewe), The Church and the squatters/informal settlements (Kerk en Plakkers) and numerous smaller research projects. The following themes were selected as priority in 1988 and were continued throughout the nineties:

- The history of mission in southern Africa (including Crafford's research on black pioneer missionaries)

- Theological developments in southern Africa (including the independent black churches)

- Ecumenics in southern Africa (Crafford, Meiring and Gous)

- Other religions in southern Africa

- The church's response to the needs of the community (more about this later)

- The broadly formulated field of 'Challenges for mission in southern Africa'.

In Deo Gloria (Yearbook of the Faculty of Theology) Cronje wrote in 1990 (p. 19) that IMER's publications provide important support to the mission work of the DRC, covering African traditions, Zionists in Transkei (now Eastern Cape), Chinese in SA, church history of SWA/Namibia (now Namibia), the role of women in the mission field, the subsidisation of young churches, etc. Future publications would cover themes such as Church and development, Mission and Ecology and Ecumenical Relations.

These titles reflect the growing importance of social issues such as poverty, the environment and human and church relations. It seemed, however, as if the church lacked the energy to tackle these problems and see them through to the end.

Cronje, aged 79, received the Chancellor's Medal from UP in 1993. The Faculty of Theology recommended him 'for his service to the church, community and the faculty' (letter from the dean, Professor W.S. Prinsloo, 1993.06.22). In his acceptance letter to the rector, Professor Flip Smit, Cronje wrote:

Whereas this award is primarily for my work in mission, I really appreciate the fact that the work of the church in this field is also recognized and applauded. In the past 100 years since the DRC has been active in this field both locally and overseas, many universities bestowed honorary degrees to Bible translators and pioneers in the medical and educational fields. Yet, as far as I know, this is the first time that a university acknowledges the importance of mission work. For this I extend my heartfelt gratitude and give all the glory to God... .

(1993.06.29, translation AvN)

This letter contains, perhaps, for the time being, the last reference to the 'great mission work of the DRC' as something that exists in the present and not in the past.

\section{INSECURITIES HIT IMER}

The award of the Chancellors Medal to Cronje was a high point in the history of IMER. But, at the same time, it marked the end of the good times. The award referred to the past and not to the future. The insecurities of the nineties now started to dominate the situation. By 1995 IMER had only an uncertain future. Outside the university the missionary movement of the 20th century was declining and the structures at the university would be negatively impacted by this decline.

In 1995 Kritzinger moved out of IMER's full-time service and became a professor in the Department Science of Religion and Missiology, although he stayed on as part-time Director until his retirement in 2002 and continued to regard IMER as a high priority. No full-time successor was appointed. By 1997 the university terminated the post of Director and Researcher at IMER. Kritzinger expressed his shock in a letter to the dean on 28 August 1997, although it was not totally unexpected. IMER had no more permanent posts and had to find other ways to survive. The termination of the post was due to the dramatic cuts that were caused by the university's financial situation and it was not aimed against IMER as such ( $c f$. the remark made by the dean, Professor Conrad Wetmar, Minutes of the meeting of the IMER Management, 11 Sept 1997, 4.1.2) However, the fact remained that IMER was not a priority to the university. 
Before considering whether a new phase had arrived, other activities of IMER will be considered.

\section{PUBLICATIONS AND DATABASE}

Missions are never (or should never be) executed without thorough reflection. Research must always be a basic element of any missionary work. This was the reason why the DRC established IMER in the first place - to stimulate and co-ordinate research. This resulted in the establishment of a database and numerous publications.

From the beginning one of IMER's tasks was to collect and preserve material on missionary work that did not qualify for the church archives (Crafford 1982:485). In 1989 the church Archivist Dr G.C. Kotzé requested IMER to assist with the indexation of minutes and church periodicals such as Die Kerkbode and Die Voorligter. At this stage IMER had already been working for five years on its own data bank - in which about 7000 data record cards had already been indexed. It was decided to co-operate with the church's archive to computerise the data bank.

IMER's most important output was publications. When IMER had to publish some of its studies, a brother of Cronje made a donation that led to the establishment of the Cronje Publication Fund. This fund played an indispensable role to publish studies that could not be published readily elsewhere, but were important enough to print in small quantities. IMER could produce them quickly and at low cost. The fund was managed as a revolving fund - it made a minimum profit but income from sales was returned to the fund. The fund grew when IMER purchased books from other publishers that did not sell well and resold them at a cheaper price to students. The fund was managed according to business principles - an approach that became increasingly important afterwards.

IMER used three methods to produce publications: An IMER publication published by an established publisher, IMER's own publications, and a few that appeared as publications from Stellenbosch Theological Studies.

Crafford published Uitdagings vir die Kerk in Afrika (Challenges to the church in Africa), a compilation of study notes and articles from the eighties, in 1990. He edited the book Trailblazers of the Gospel. Black Pioneers in the Missionary History of Southern Africa (1991). He also gave a number of important lectures that were to benefit IMER: Sendingwetenskap Waarheen? (Inaugural lecture of 1989); Onafhanklike Swart Kerke in Suid-Afrika; and Mission in a Multi-Religious Context (1995 IMER Lecture).

Several IMER publications appeared at the NG Kerkboekhandel in Pretoria: Kritzinger's ‘n Missionere bediening - op weg na strukture vir 'n jong kerk in 1979; W.J. van der Merwe's From mission field to autonomous church in Zimbabwe, C.W.H. Boshoff's Swart Teologie vanaf Amerika tot in Suid-Afrika, 1980; J.M. Cronje's Vroue met nardusparfuum. Die aandeel van die vrou in die sendingwerk van die Nederduitse Gereformeerde Kerk in 1984. In 1993 D. Crafford en Gustav Gous's Een liggaam - baie lede. Die kerk se ekumeniese roeping werreldwyd en in Suid-Afrika was published as an IMER publication at Verba Vitae, Pretoria.

IMER also published its own books, such as J.M. Cronje: Die subsidiering van Jongkerke, 1981 and Die Sjinese in Suid-Afrika en hulle gosdsdiens, 1982. H.L. Pretorius' Bitter as the juice of an aloe, on the Independent Churches of Africa appeared in 1983, followed by Sound the trumpet of Zion in 1985. Eddie Bruwer's book: Beggars can be choosers. In search of a better way out of poverty and dependence, was published as a joint venture with the Uniting Reformed Church's 'Church Aid in Need' in 1994. It was reprinted in 1996, 2001, and in 2008 - one of the success stories. Salig die vredemakers. ' $n$ Geskiedenis van die Kerk in SWA/Namibië, by J.J. Kritzinger and G.L. Buys appeared in 1989. Joyce Scott's Tuning in to a different song. Using a music bridge to cross cultural differences of 2000 was an excellent publication. David J. Bosch's A spirituality of the road went out of print and IMER obtained permission to publish it in 1994. Deon Loots produced two practical works: Short-term outreach in the African context in 1996 and Is ek ook geroep? in 1998. In 2001, Perspectives on Christianity. $1948+50$ years theology, apartheid and church: Past present and future with J.W. Hofmeyr, C.J.S. Lombard and P.J. Maritz as editors was published, as well as Sending in Soedan 1922-1934 by D.B. de Vos, J.P. Mostert (pioneer in KZN) wrote a book Die Engele het seker ook geglimlag on the early days of DRC missions in Natal; Frans Hancke's Ons is die Plan. Die gemeente met ' $n$ verskil word ' $n$ verskil was published in 2005.

Stellenbosch Theological Studies published an IMER publication as their Study Number 16: Die aantrekkingskrag van die Marxisme in die Derde Wêreld, by J. du Preez, a professor in Missiology at Stellenbosch University. It was published through the NG KerkUitgewers, Cape Town by the Stellenbosch section of IMER. It was followed by Study Numbers 18 and 19, Sendingperspektiewe in die erediens in 1992. This section of IMER did not function for very long.

IMER Communication appeared for the first time in June 1979. Numerous topics of interest were addressed over the years and the last issue, Volume 20:1 appeared in 1998, entitled: Sending: Nuwe horisonne, nuwe moontlikhede.

Many churches and missionary organisations are doing research, frequently without them knowing about each other. IMER is the only one that is connected to a university, with all the privileges this entails. In a sense, IMER can be seen as the flagship of missionary research in the country. It was for this reason that a call that Kritzinger made to the various institutions to discuss cooperation was readily accepted. MISNET (Missionary Research Network) was established as a result in the late nineties. MISNET is well positioned to coordinate research. The first joint project, a follow-up on IMER's Unfinished Task was the publication No Quick fixes. The challenge of mission in a changing South Africa with Kritzinger as editor. This was his last large project for IMER, and it comprises 14 chapters written by various writers.

\section{NEW ROADS?}

Van der Watt described the nineties in terms such as: A diversity of approaches, the initiative shifted to the congregations, world mission, and uncertainty. Is it possible to start identifying the next phase in mission? This question is extremely important for the future of IMER and for the DRC mission in the century that lies ahead.

In No Quick Fixes (2002), Kritzinger (pp. 199-2006) identifies five dimensions within the SA context: The religious, political, economical, social and ecological dimensions. In this book, IMER is grappling with the 21st century. The difficult task to study our context as a church and understand our calling has started.

Four factors that may, in combination, prove to be relevant to IMER's future will be discussed below: Developments at the university, at the congregations, at the general synods and at the Nova Institute with which IMER co-operates. The golden thread through all of these is the development of resources for integrating the social role of the church in her witness to the world - which is also referred to as 'mission and service' or the ministry to the community.

\section{Developments at the university}

At a strategic planning meeting of UP at Loskopdam in 1988, it was mentioned that the largest contributor to the university's funding was the government, that its role was decreasing and that planning had to be done accordingly. A document from this meeting advised that UP investments must be dealt with on business principles' ('BYLAE F 9-11 FEBRUARIE 1988', p. 7). 
In the years to follow, the term business principles became increasingly more important to the university. Here Jansenn and Proot's profit motive appears again. The government has remained the main source of income for the university and the university has to abide by the policies of government. But, while political pressure is seen as a hurdle to growth, the university is thinking more and more in terms of business principles, as this could lead to growth through innovative action.

The term innovation has become a theme at UP: Innovation is described as a new idea and acceptance by the market. While academic theses and articles are texts that must be approved by two other academics and where research leads to publications, innovation means to develop suitable solutions (technology, procedures, techniques, methods) to concrete problems, solutions that are approved by the users or consumers - the market. This also requires scientific approaches and methods, with this difference: The end result is not a publication but a tested design that can be implemented in practice.

Innovation is related to the concept of entrepreneurship, which has become important in all professions. Innovation has become equally important to IMER, to mission itself and even to congregational ministry itself.

\section{Developments at the congregations}

Kerkspieël 2004 (Schoeman \& Bischoff 2004), a survey of trends in the DRC, found: 'Slightly less than half of the congregations are dying or are fighting for survival...congregations in the countryside and those with less than 600 members are fighting for survival' (Schoeman \& Bischoff 2004:n.p.).

But financial hardship is not the only problem. Congregations seemingly do not understand their calling to mission and to the world. All their energies are taken up by the battle for survival and to maintain themselves, while, ironically, innovation and reaching out to the world may be their only chance to survive: 'A unique pattern of service, wider than the usual duties of the minister, ought to be developed for these congregation' (ibid. 2004:42,43).

The recommendations of Kerkspieel 2004 reflect the same way of thinking that led to the changes happening at the university. Innovative approaches are required for new circumstances. Local congregations can flourish again by developing opportunities for caring for vulnerable children, assisting the unemployed to maintain their families, and in caring for terminal patients. This leads to the natural combination of word and deed in the church's witness to the world.

However, those congregations that are fighting for their survival require resources such as knowledge and skills, funding and support networks to enable them to provide those services. These resources can usually not be developed by a congregation, it is the task of the general synod.

\section{Developments at general synods}

In 1998 the General Synod of the DRC appointed the socalled VAM Commission (the Commission for Reconciliation, Poverty and Morality) to formulate guidelines for the church's vast responsibility to co-operate with other churches in giving attention to the following urgent matters: promoting reconciliation and combating poverty and the decline of moral standards in South Africa (Handelinge 1998:402). Kritzinger and Attie van Niekerk, a part time researcher at IMER since 1997, were appointed to this commission.

On recommendation of the VAM Commission, the DRC marked 2001 as 'The Year of Hope'. With renewed vigour, the church decided to dedicate itself to God by seeing the hopelessness in the world, to think about what can be done and then to do something about it. One of the three publications that formed part of the
'Year of Hope' series was published by IMER: Hoop in nood (Hope in need). Another title: 'Op pad na versoening' (The road to reconciliation) was written by a member of IMER's management board and chairman of VAM, Professor Piet Meiring, professor in Missiology at UP.

In the early 21st century, small signs of hope have emerged throughout the DRC as a new awareness of its calling in the country rises along with new initiatives in unifying the church and in combating poverty.

In 2002 the General Synod of 2002 issued a Declaration in which she recommitted herself to her calling, to the Lord who established our church here 350 years ago, and to our continent, especially to Southern Africa, and to greater unity with other churches. The Synod called on congregations to contribute to the healing of our land. The Declaration ends with: 'We have a God. We are here. We are his church.' This Declaration reveals the transition from the previous century, in which the church talked the language of power, that ended in uncertainty, to the rediscovery of a deeper commitment and awareness of our calling. With this, the DRC wants to find her place and role amongst other churches and in the country. It picks up the trail of Jansenn and Proot's report in 1650, and Du Plessis's view in the 1920's of the DRC as a mission church with a broad social responsibility, where politics is no longer a driving force.

However, the church lacks the resources (knowledge, funding and networks) to attend to this meaningfully. The general synods of four members of the DRC family were appointed to form a joint commission. The task of this commission was to develop a program for assisting local congregations to attend to poverty, economic imbalances, HIV/AIDS and peace and justice. Van Niekerk was a member of this commission and the project leader responsible for its strategic development. IMER was tasked to develop the resources for the program, but IMER itself first has to develop the capacity to do so.

After Kritzinger's retirement in 2002, Van Niekerk became the director of IMER. The subsidy received from the General Synod was IMER's only fixed income, and it was not enough to even pay for the salary of a secretary. It was later phased out altogether. No fixed annual funding is available anymore for any research or salaries. What remains is the church's calling to mission and the search for structures in which it can be manifested. These structures will have to follow the new approach at the university, described by terms such as business principles, innovation and entrepreneurship. With this approach IMER can obtain funding from the general synod, and from other sources outside the church, for specific research projects. IMER is not limited by a fixed income anymore but can grow by developing new opportunities. This is quite possible. It is also possible however, that the plans may not work out and that IMER dies. IMER is, in other words, in the same situation as the church's mission and many congregations: a new economic basis must be found that fits in with the DRC's calling in this hour and context.

IMER is becoming an opportunity rather than a stable organisation. IMER writes project proposals for income and cannot depend on fixed subsidies. The loss in security is rewarded by the increase in opportunity and adaptability. In this, IMER's position between church and university is strategically important as it presents opportunities to network and promote synergy between role players.

The main question is, however, how the DRC, the DRC family and other churches in South Africa will understand their calling in this hour and whether IMER has a role to play in this. The role of mission remains to bring people to faith in Jesus Christ and to understand the implications of this faith for the whole of life. As the context changes, suitable ways and structures must develop to remain faithful to this calling. This remains our unfinished task. 


\section{New networks}

On 9 October 1992 IMER's management decided in principle to co-operate with the newly established Nova Institute, as and when opportunities presented themselves. At that stage Van Niekerk was still a professor in Practical Theology at the Stofberg Theological School at the University of the North, but this institution was closing down and he was busy with the establishment of a not-for-profit organisation, the Nova Institute. Nova's purpose is to fight poverty through research and development, i.e., to develop workable solutions for concrete problems. This fits in with the university's later emphasis on innovation. Later on, Nova's approach was described by terms such as participative action research and practice research.

Nova had to generate its income through projects done on contract, primarily for industry and government departments.

In 1997, Van Niekerk was appointed as temporary, part-time researcher at IMER, to focus on the church's role in fighting poverty. His post was funded by a combination of funds that IMER had accumulated, ad hoc contributions from synods, and through contract work, e.g. a project for the Bible Society in which methods to make the Bible available to those who are illiterate were investigated. He lectured in Missiology on an ad hoc basis, for example in Meiring's place when he was appointed to the Truth and Reconciliation Commission in 1997, for two years. When Kritzinger retired as professor in Missiology at the Faculty of Theology in 2002, his post was terminated by the university, but the curatorium has so far maintained its contribution of about a third of the post and these funds are used to appoint Van Niekerk as part-time lecturer, which establishes a bridge between Nova, IMER and the Faculty of Theology.

The co-operation between Nova and IMER is embodied in the Functional Household Programme (FHP) at the Faculty of Theology. The FHP brings together researchers from different disciplines to work on specific problems experienced by lowincome households. Depending on the given problem a team is formed, comprised of engineers, theologians, architects, botanists, philosophers, medical doctors, and/or psychologists, along with residents of low-income housing. This group works through various processes to develop meaningful solutions that can be tested, evaluated, improved and eventually implemented in practice. A number of technical solutions are usually available for a given problem, but the most suitable one has to be selected and redesigned in order to functionally integrate it into the existing cultural, economic and ecological systems and processes. This approach brought success to Nova when it developed a simple method to drastically reduce air pollution caused by the domestic use of coal stoves. This success was seen by Nova as nothing less than a gift of grace. It led to co-operation with industries such as Sasol, various government departments and with the Fair Climate programme of ICCO/Kerk in Actie of the Protestant Church in the Netherlands. This has led to various new opportunities.

Nova's contracts with industries qualified it for funding from THRIP (Technology and Human Resources for Industry Programme) of the national government's Department of Trade and Industry. The department instituted THRIP to support research and development that would promote the competitiveness of industries in the country. In September 2005 the FHP received the THRIP Excellence Award for Social Development from the minister of Trade and Industry. This award acknowledges that FHP has developed an approach that is to the advantage of both industry and the society. This is especially important coming from a sphere where the church and theology are seldom seen and acknowledged.

Nova has developed into a fine team of young, full-time researchers who graduated from the Faculty of Theology. Nova is currently focusing on key aspects of low-income households:
Energy (led by Dr Cristiaan Pauw), caring for vulnerable children (led by Dr Montagu Murray), home-based production (led by Riaan Ingram) and housing (led by Hendrik Snyman). The work is growing steadily. New dreams are being dreamed. Whereas the Chancellor's Medal was awarded to the 79-year-old Dr Cronje in 1993 to acknowledge the DRC's mission work in the 20th century, one hopes that the THRIP award to a team of young researchers is an indication of a new phase in mission.

\section{THE ROAD AHEAD?}

Various indicators may help IMER to find a way into the future:

\section{Global}

It often seems as if the 21st century is going to be an apocalyptic one, with its global ecological disasters and pandemics such as HIV / AIDS causing massive numbers of deaths, and the threat of scarcity of food and water. More and more churches are taking hands with other institutions to respond to these problems. New opportunities are presented to IMER and local missions, for example IMER's association with ICCO/Kerk in Actie of the Protestant Church of the Netherlands via Nova. A new movement, to sustain the ecology, may perhaps prove to be the next wave that takes the church's mission forward.

\section{Africa}

According to Tony Blair's Report on Africa (2005:33), politics has lost the ability to mobilise the people of Africa to improve their lives, and religions - including the Christian church - have taken over this role. If this is true, it holds numerous implications for the church in Africa that have to be considered.

\section{National}

The DRC is in the process of formulating her role in the 21st century. IMER's task in this process - on which it is already hard at work - is to develop resources for local congregations to combine evangelism with combating poverty and suffering. It is already clear that the end of apartheid is not the end of poverty, as the rich are still getting richer and the poor, poorer (Pauw et al. 2007). At the beginning of this century the number of people that are HIV positive is more than the number of all people in the country a century ago - it could possibly even be twice as many. We do not yet understand the implications of this, because we have never experienced a pandemic of the extent and nature of this one before. If our previous experience is no longer sufficient to supply answers for today, then new knowledge is crucial to the life of the church and the country. New research methods, such as practice research, are needed to be able to understand and deal with new problems, driven by a new sense of our calling as witnesses of the hope that is in Christ Jesus.

\section{University}

IMER is formally established at UP and fits in well with the new developments at the university. Although no financial resources are provided by the university, numerous opportunities are obtained through our association with them.

\section{Congregations}

IMER sees the expansion of the ministry from maintaining the congregation to serving the local community as the obvious answer to the recommendations of Kerkspieël 2004, that new patterns of ministry are needed. Should this happen, then mission in the 21st century will not be done only by missionaries, but also by local churches in their local communities, in a more holistic way than before.

\section{Missiology}

Missiology teaches us that mission should respond to the whole person and all his/her needs. A holistic ministry involves kerygma (proclaiming the gospel), koinonia (christian relations with people) and diakonia (caring for people's daily needs), all three coming from and leading back to the liturgy or church 
service where the congregation is brought together by God. The question that remains is to understand the interfaces and interactions between these dimensions. The best type of mission work will be an approach in which all four are so interdependent that they are inseparable within the concrete reality and world of people in need.

\section{REFERENCES}

Blair, T., 2005, Our common interest. Report of the Commission for Africa, Commission for Africa, London.

Crafford, D., 1982, Aan God die dank. Geskiedenis van die sending van die Ned. Geref. Kerk binne die Republiek van Suid-Afrika en enkele aangensende Buurstate. Deel I, NG Boekhandel, Pretoria.

Cronje, J.M., 1990, 'ISWEN bied inligting, hulp en raad', in Deo Gloria 1990, p.19, Fakulteit Teologie, Universiteit van Pretoria, Pretoria.

Cronje, J.M., 1993, Motivering vir die toekenning van die Kanseliersmedalje...Notule van die Senaat, UP S785/93, p. 6.
Du Plessis, J., 1911, A history of Christian missions in South Africa, Longmans, London.

Giliomee, H., 2004, Die Afrikaners. 'n Biografie, Tafelberg, Kaapstad.

Kritzinger, D. (ed.), 2002, No Quick fixes. The challenge of mission in a changing South Africa, IMER, Pretoria.

Pauw, K. \& Mncube, L., 2007, The impact of growth and redistribution on poverty and inequality in South Africa Development Policy Research Unit, University of Cape Town, for the International Poverty Centre, United Nations Development Programme.

Schoeman, K. \& Bischoff, J., 2004, Kerkspieël 2004. Verslag aan die Algemene Sinode, unpublished synod report.

Van der Watt, G., 2003, ‘Die Sendingpraktyk van die Ned Geref Kerk: Enkele tendense vanaf 1952 tot met die eeuwenteling', Verbum et Ecclesia 24(1), 213-231. 